\section{Livsfarlig «tverrfaglighet» uten medisinsk behandlingskjede}

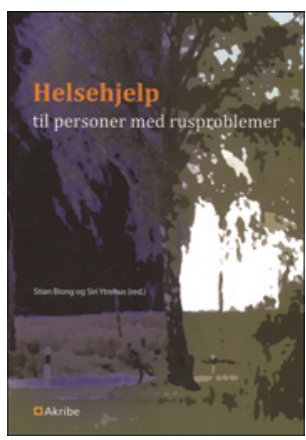

Stian Biong, Siri Ytrehus, red Helsehjelp til personer med rusproblemer 283 s, tab, ill. Oslo: Akribe, 2012.

Pris NOK 420

ISBN 978-82-7950-160-2

Hverdagen for mange tusen unge pasienter: Neste injeksjon med urent stoff kan medføre alvorlig skade eller død. Overdosedødsfall er tredje hyppigste dødsårsak i aldersgruppen 15-44 år, etter suicid og kreft. Manglende akuttbehandling, diskriminering og systematisk feilbehandling $i$ helsevesenet ligger til grunn.

I denne boken ønsker de 14 forfatterne å bedre helsehjelpen til utsatte og ressurskrevende pasienter som lider under skadelig bruk av psykoaktive stoffer som alkohol, opioider og benzodiazepiner.

En kritisk svakhet dominerer: Boken tilslører legens rolle og mangler en tydelig behandlingskjede og klare medisinske tiltak, med fare for at mange leger, sykepleiere og sosionomer fortsetter å trivialisere livstruende tilstander. De gode intensjonene bør derfor suppleres med nettressurser eller en e-bok-utgave som presenterer en sammenhengende medisinsk behandlingskjede, særlig med konkret prosedyre for akutt substitusjonsbehandling som overdoseprofylakse.

Det overrasker meg at professor Bramness anbefaler bråseponering av opioider, såkalt «cold turkey», i stedet for en human og symptomstyrt nedtrapping med opioider. Man unnlater dertil å nevne at tvungen nedtrapping av opioider, såkalt avrusning/ avgiftning, har så høy dødelighet at det ikke er medisinsk behandling per se.

Nedtrapping av benzodiazepiner og hypnotika kan være en utfordring for pasient og allmennlege, men er spartansk omtalt. Jeg savner konkrete strategier for å sikre behandling til pasienter som avviser at de har problematisk bruk av alkohol eller beroligende. Til gjengjeld anbefaler Bramness forbilledlig professor Heather Ashtons nettbok med prosedyrer for nedtrapping av benzodiazepiner.

Forfatterne har gått grundig gjennom overdosedødsfall, men det mangler et kritisk blikk på legemiddelassistert rehabilitering (LAR) og manglende nedgang i overdosedødsfall totalt. Et kapittel om sykepleie til pasienter med skadelig opioidbruk innlagt på somatisk sykehus, skrevet av Anne Skoglund og Stian Biong, er befriende konkret og medisinsk interessant også for leger.

I kapitlet om etikk savner jeg at forfatterne belyser brudd på pasient- og menneskerettigheter, f.eks. når

1. leger nekter å gi kjent behandling for en livstruende tilstand

2. ikke-medisinske kriterier styrer medisinsk behandling

3. forskning bryter Helsinki-deklarasjonen

4. tvungen nedtrapping av opioider setter liv i fare

5. intoksikerte pasienter settes i politiarrest i stedet for å legges inn i sykehus.
Grunnideen inspirerer: Når man er sensitiv for pasientens behov og de positive intensjonene bak pasientens atferd, kan man hjelpe pasienten med å utvide repertoaret av løsninger som er naturlige for ham eller henne: «Selv en enkelt samtale med en aksepterende person kan bidra til endring. Ved å spørre etter pasientens egen oppfatning av hva han eller hun trenger, skaper behandleren et terapeutisk rom som pasienten kan benytte seg av.»

Respekt for pasienten tilsier en profesjonell språkbruk med deskriptive termer som «skadelig bruk». Det er forstemmende at forfatterne henfaller til det normative og stigmatiserende begrepet «rus», til tross for at man skriver at dette begrepet er særnorskt, og at det ikke brukes i engelsk, tysk eller fransk faglitteratur. Eksempel: Senter for rus- og avhengighetsmedisin heter på engelsk Centre for addiction research.

Bidragsyterne deler medisin i somatikk, psykiatri og «rus». Man kan spørre seg om dette nye «rusfeltet» med sin tverrfaglig spesialiserte behandling (TSB) er psykiatriens fallitterklæring der krevende medisinsk behandling overlates til «behandlere» uten formell medisinsk kompetanse. Forfatterne skriver rett ut at «såkalt tverrfaglig spesialisert behandling» mangler konkret innhold.

De drøyt 400 litteraturhenvisningene dokumenterer rådende behandlingskultur i Norge, med få fagfellevurderte artikler og en dominans av lover, forskrifter, offentlige utredninger, stortingsmeldinger, rådslag, kunnskapsgjennomganger, konferanseoppsummeringer og rapporter. Pasientens stemme mangler, og jeg savner kasuistikker og håpsfortellinger fra erfarne leger med førstehåndskunnskap fra feltet.

Skal forfatterne forbedre behandlingen av pasienter med skadelig stoffbruk, må man supplere med en sammenhengende medisinsk behandlingskjede med konkrete akuttprosedyrer og intervensjoner. Uten et slikt supplement mener jeg at boken om tverrfaglig spesialisert behandling feilinformerer leger, sykepleier og sosionomer, hvilket kan bli direkte farlig for pasienter.

Joe Siri Ekgren

Avhengighetsmedisinsk forening 